\title{
Technological, microbiological and chemical characteristics of Pannerone, a traditional Italian raw milk cheese
}

\author{
Germano Mucchetti ${ }^{1 *}$, Roberta GHiglietti ${ }^{2}$, Francesco LocCI $^{2}$, \\ Salvatore Francolino ${ }^{2}$, Barbara BonvinI ${ }^{2}$, Maria Chiara REMAGNI ${ }^{2}$, \\ Miriam $\mathrm{ZAGO}^{2}$, Romina IEZZI ${ }^{1}$, Domenico CARMINATI ${ }^{2}$ \\ ${ }^{1}$ Dipartimento Ingegneria Industriale, Università degli Studi di Parma, \\ Parco Area delle Scienze, 43100 Parma, Italy \\ ${ }^{2}$ CRA-FLC Centro di Ricerca per le Produzioni Foraggere e Lattiero Casearie, \\ Via Lombardo 11, 26900 Lodi, Italy
}

Received 20 October 2008 - Revised 16 March 2009 - Accepted 26 March 2009

Published online 16 June 2009

\begin{abstract}
Pannerone cheese is a cow raw milk cheese obtained without starter and salt addition, which can be classified as a semi-soft cheese with a high fat content. Prolonged holding of moulded curds at warm room temperatures $\left(\sim 30^{\circ} \mathrm{C}\right)$ was identified as having a key role in the cheese microbiological and chemical composition. Microbial populations were numerous and diverse with high numbers of lactic acid bacteria and coliforms. Pathogenic bacteria were not detected, while propionic bacteria and spores of lactate-fermenting clostridia were detected in all samples. Changes in microbial populations corresponded with key changes in chemical composition. During the first 2 days in the warm room at $30^{\circ} \mathrm{C}, \mathrm{pH}$ decreased to 4.9 and lactose was completely fermented to lactic acid. Over the next 4 days, metabolism of lactate to butyric $\left(7.5 \mathrm{~g} \cdot \mathrm{kg}^{-1}\right)$ and propionic $\left(1.7 \mathrm{~g} \cdot \mathrm{kg}^{-1}\right)$ acids with a consequent increase in $\mathrm{pH}$ to 5.7 occurred. The importance of the warm room temperature was demonstrated. The incubation of moulded curd had to be carried out at temperatures of about $30^{\circ} \mathrm{C}$ to obtain the typical fermentation profile. The addition of lysozyme to the vat milk prevented the formation of high level of butyric acid typical of Pannerone cheese, thus demonstrating the involvement of lactate-fermenting clostridia in the production of butyric acid.
\end{abstract}

Pannerone cheese / clostridia / butyric acid / propionic acid / cheese-making technology

\begin{abstract}
摘要 - 传统意大利生乳干酪 Pannerone 的加工、微生物及化学特性。Pannerone 干酪是一 种用生鲜牛乳经自然发酵不加盐的高脂肪半软质干酪。有资料显示成型的凝块长期放置在温 暖的室温 $\left(\sim 30^{\circ} \mathrm{C}\right)$ 下是干酪微生物和化学成分变化的关键原因。其中含有大量的、种类 繁多的乳酸菌和大肠菌群。没有致病菌检出, 但所有产品中均含有丙酸菌和梭状芽孢菌。微 生物菌群的变化与主要化学成分的变化直接相关。在最初的 2 天里, 在室温下 $\mathrm{pH}$ 值下降 到 4.9 , 乳糖完全发酵成乳酸。接下来的 4 天中, 乳酸代谢为丁酸 $\left(7.5 \mathrm{~g} \cdot \mathrm{kg}^{-1}\right)$ 和丙酸 $\left(1.7 \mathrm{~g} \cdot \mathrm{kg}^{-1}\right), \mathrm{pH}$ 值持续升高到 5.7。同时, 还证实了温暖室温的重要性。凝块必须放置 在 $30^{\circ} \mathrm{C}$ 下, 才能获得典型的发酵特性。将溶菌酶添加到原料乳中阻止了高含量典型的 Pannerone 干酪丁酸的形成, 由此也证实了梭状芽胞杆菌能发酵乳酸盐产生丁酸。
\end{abstract}

\section{Pannerone 干酪 / 梭状菌 / 丁酸 / 丙酸 / 干酪制作技术}

*Corresponding author (通讯作者): germano.mucchetti@unipr.it 
Résumé - Caractéristiques technologiques, microbiologiques et chimiques du Pannerone, un fromage italien traditionnel au lait cru. Le Pannerone est un fromage au lait de vache cru obtenu sans ajout de levain ni de sel, qui peut être classé comme fromage à pâte mi-molle à teneur élevée en matière grasse. Le maintien prolongé des caillés moulés en chambre chaude $\left(\sim 30^{\circ} \mathrm{C}\right)$ a été identifié comme ayant un rôle clé sur la composition microbiologique et chimique du fromage. Les populations microbiennes étaient nombreuses et diverses avec des nombres élevés de bactéries lactiques et de coliformes. Les bactéries pathogènes n'étaient pas détectées alors que les bactéries propioniques et les spores de clostridia fermentant le lactate étaient détectés dans tous les échantillons. Les changements dans les populations microbiennes correspondaient à des changements clés dans la composition chimique. Au cours des 2 premiers jours en chambre chaude à $30^{\circ} \mathrm{C}$, le $\mathrm{pH}$ descendait à 4,9 et le lactose était complètement fermenté en acide lactique. Les 4 jours suivants, le métabolisme du lactate en acide butyrique $\left(7,5 \mathrm{~g} \cdot \mathrm{kg}^{-1}\right)$ et en acide propionique $\left(1,7 \mathrm{~g} \cdot \mathrm{kg}^{-1}\right)$ et une augmentation conséquente du $\mathrm{pH}$ à 5,7 avaient lieu. L'importance de la température en chambre chaude était démontrée. L'incubation du caillé moulé devait se faire à des températures d'environ $30^{\circ} \mathrm{C}$ afin d'obtenir le profil de fermentation typique. L'addition de lysozyme au lait de fabrication empêchait la formation de niveaux élevés d'acide butyrique typique du fromage Pannerone, démontrant ainsi l'implication des clostridia fermentant le lactate dans la production de l'acide butyrique.

fromage Pannerone / clostridia / acide butyrique / acide propionique / technologie fromagère

\section{INTRODUCTION}

Pannerone cheese is traditionally produced near Lodi (Italy), nowadays only in two dairies. This cheese has a cylindrical shape, with a diameter of $28-30 \mathrm{~cm}$, a height of about $20 \mathrm{~cm}$ and a weight of $10-13 \mathrm{~kg}$. Pannerone is an unsalted cheese obtained with unrefrigerated cow raw milk and without the use of lactic starter culture. Its production is characterized by milling of the curds by hand before moulding and by a prolonged holding of the moulded curd in a warm room at a temperature of about $29 \pm 2{ }^{\circ} \mathrm{C}$ up to 7 days. This is then cooled to $4-10{ }^{\circ} \mathrm{C}$, and it is ready for consumption after 10-12 days from the start of cheesemaking, but it can be stored for at least 2 months [22, 26]. The interior of the cheese has a sponge-type structure, with a large number of eyes of different sizes produced by heterofermentative lactic acid bacteria (LAB), yeasts, Enterobacteriaceae [23] and propionic acid bacteria (PAB) [5]. Ottogalli et al. [23] did not isolate butyric clostridia from Pannerone cheese, but their study did show that within 8 days of cheese-making the butyric acid was $79.4 \%$ of the sum of the volatile-free fatty acids.

The chemical composition of Pannerone cheese is characterized by moisture, fat, protein and ash contents of about $50 \%, 26 \%$, $21 \%$ and $2.4 \%$, respectively $[26,29]$. The $\mathrm{pH}$ value ranges from 5.4 to $5.8[5,23]$, but it is unknown if these $\mathrm{pH}$ values are due to cessation or inhibition of lactic acid fermentation or due to lactate utilization by non-LAB microflora, for example PAB, yeasts or moulds. No data are known about the carbohydrate and organic acids contents of Pannerone cheese.

The aim of this work was to relate the microbiological and chemical composition of Pannerone cheese to its particular cheese-making technology, demonstrating both the key role of the prolonged stay of the curd in the warm room and that of lactate-fermenting clostridia in the complex fermentation of this cheese. 


\section{MATERIALS AND METHODS}

\subsection{Pannerone cheese samples}

Twenty-six Pannerone cheeses ready for consumption were sampled directly at the dairy or from retail and were analysed for microbiological and chemical compositions.

\subsection{Microbiological analyses}

Ten grams of cheese were mixed in $90 \mathrm{~mL}$ of sterile $2 \%$ trisodium citrate buffer, $\mathrm{pH} 7.5$, and blended for $2 \mathrm{~min}$ with a Stomacher 400 Circulator (PBI, Milan, Italy). Decimal dilutions of the stomacher fluid were made using sterile quarter-strength Ringer's solution as diluent. The dilutions were used for the enumeration of bacteria by conventional microbiological methods.

Lactococci were enumerated on M17 agar (Merck, Darmstadt, Germany) after incubation at $37^{\circ} \mathrm{C}$ for $48 \mathrm{~h}$. Lactobacilli were enumerated on deMan Rogosa Sharpe (MRS) agar (Merck), under anaerobic conditions, after incubation at $37^{\circ} \mathrm{C}$ for $48 \mathrm{~h}$. Heterofermentative LAB were determined on MRS broth with Durham's tubes at $37^{\circ} \mathrm{C}$ for $48 \mathrm{~h}$, on the basis of the last dilution which showed gas formation in the tube. Enterococci were enumerated on kanamycin aesculin azide (KAA) agar (Merck) after incubation at $42{ }^{\circ} \mathrm{C}$ for $48 \mathrm{~h}$. Yeasts and moulds were enumerated on yeast glucose chloramphenicol (YGC) agar (Merck) after incubation at $25{ }^{\circ} \mathrm{C}$ for 5 days. Lipolytic bacteria were enumerated on tributyrin agar (Oxoid, Milan, Italy) at $30{ }^{\circ} \mathrm{C}$ for $72 \mathrm{~h}$. Coliforms and Escherichia coli were enumerated on plates of Coli-ID agar (Biomérieux, Rome, Italy), after incubation at $37^{\circ} \mathrm{C}$ for $24-48 \mathrm{~h}$. Coagulase-positive staphylococci were enumerated on plates of Baird Parker RPF agar (Biomérieux) after incubation at $37^{\circ} \mathrm{C}$ for $48 \mathrm{~h}$. PAB were enumerated on $\mathrm{Pal}$
Propiobac agar (Laboratoires Standa, Caen, France) after incubation at $30^{\circ} \mathrm{C}$ for 6 days under anaerobic conditions [27]. Enumerations of anaerobic lactate-fermenting clostridia were carried out on tubes of Bryant Burkey Modified Broth (BBMB) (Biolife, Milan, Italy) using the most probable number counting technique. After heat treatment at $80{ }^{\circ} \mathrm{C}$ for $15 \mathrm{~min}$, to kill vegetative cells and activate spores, $1-\mathrm{mL}$ aliquots of sample or dilution were inoculated into each of the three tubes containing $9 \mathrm{~mL}$ of BBMB broth. After inoculation, the tubes were sealed by addition of a layer of paraffin (about $15 \mathrm{~mm}$ thick), incubated at $37{ }^{\circ} \mathrm{C}$ for 7 days and observed for gas production [8]. Detection of pathogens were carried out on $25 \mathrm{~g}$ of sample. Salmonella spp. were detected by (i) pre-enrichment in $225 \mathrm{~mL}$ buffered peptone water (Merck) at $37{ }^{\circ} \mathrm{C}$ for $24 \mathrm{~h}$, (ii) selective enrichment of $0.1 \mathrm{~mL}$ of pre-enrichment culture in $10 \mathrm{~mL}$ of Rappaport-Vassiliadis (RV, Merck) broth at $42{ }^{\circ} \mathrm{C}$ for $24 \mathrm{~h}$ and (iii) selective isolation by streaking $10 \mu \mathrm{L}$ of $\mathrm{RV}$ in duplicate onto plates of Rambach agar (Merck) at $37{ }^{\circ} \mathrm{C}$ for $24 \mathrm{~h}$. Listeria monocytogenes was detected by (i) primary enrichment in $225 \mathrm{~mL}$ of buffered Listeria enrichment broth (BLEB, Oxoid) at $30{ }^{\circ} \mathrm{C}$ for $24 \mathrm{~h}$, (ii) secondary enrichment of $0.1 \mathrm{~mL}$ of the primary enrichment culture in $10 \mathrm{~mL}$ of fresh BLEB at $30{ }^{\circ} \mathrm{C}$ for $24 \mathrm{~h}$ and (iii) selective isolation by streaking $10 \mu \mathrm{L}$ of primary and secondary enrichment in duplicate onto plates of Agar Listeria according to Ottaviani and Agosti (ALOA, Biolife) at $37{ }^{\circ} \mathrm{C}$ for $24-48 \mathrm{~h}$. E. coli O157:H7 was detected by (i) enrichment in $225 \mathrm{~mL}$ of tryptone soya broth (TSB, Oxoid) with $20 \mathrm{mg} \cdot \mathrm{L}^{-1}$ of novobiocin at $41{ }^{\circ} \mathrm{C}$ for $24 \mathrm{~h}$ and (ii) selective isolation by streaking $10 \mu \mathrm{L}$ of enrichment in duplicate onto plates on O157:H7 ID with cefixime-tellurite supplement (Biomérieux) at $37^{\circ} \mathrm{C}$ for $24 \mathrm{~h}$. 


\subsection{Chemical analyses}

The moisture, ash, fat and protein contents of the cheeses were determined according to IDF Standards 25/1964, 27/ 1964, 105/1981 and 4A/1982 [14-17], respectively. The lactose, galactose, citric acid, lactic acid, acetic acid, propionic acid and butyric acid contents of the cheeses were determined according to the HPLC method described by Bouzas et al. [6] for the simultaneous analysis of sugars and organic acids in cheese, using an Aminex HPX-87 column (Bio-Rad Laboratories, Richmond, CA, USA) and ultraviolet and refractive index detectors in series. Samples for HPLC analysis were prepared according to Bouzas et al. [6]. Twenty-five millilitres of $0.009 \mathrm{~N} \mathrm{H}_{2} \mathrm{SO}_{4}$ were added to $5 \mathrm{~g}$ of ground cheese and extracted for $1 \mathrm{~h}$ while mixing using a magnetic stirrer. The extract was centrifuged at $3000 \times g$ for $10 \mathrm{~min}$. The supernatant was filtered through a $0.45-\mu \mathrm{m}$ regenerated cellulose membrane syringe filter (Econofilter, Agilent Technologies, Germany). The $\mathrm{pH}$ was measured by means of a pH meter (Portamess 913, Knick Elektronische, Berlin, Germany).

\subsection{Monitoring of technological parameters}

Ten cheese-makings were performed at the Carena Dairy (Caselle Lurani, Lodi, Italy) and the main technological parameters used were recorded. To better understand their dynamics, for two of ten cheese productions temperature and $\mathrm{pH}$ were measured during the first 8 days of production with a frequency of one measure every $30 \mathrm{~min}$, by means of a $\mathrm{pH}$ meter (Portamess 913) and temperature data logger (Testo 177-T3, Testo SpA, Settimo Milanese, Italy) equipped with a negative temperature coefficient thermistor probe (Testo 0613 2211). Samples of milk, curd before moulding and cheese after 1, 4, 8, 12 and 32 days from cheese-making were sampled to determine their microbiological and chemical characteristics.

\subsection{Influence of the warm room step on Pannerone cheese quality}

Cheese-making trials were performed at the experimental dairy of CRA-FLC using an incubator to simulate warm room temperatures, able to contain two moulds of Pannerone, with the air temperature regulated at 4, 20, 25, 30 (control) and $38^{\circ} \mathrm{C}$. Each trial was carried out in duplicate for all the temperatures of incubation. Temperature and $\mathrm{pH}$ of cheese were monitored. Samples of milk and curd were analysed after $24 \mathrm{~h}$ and 6 days to assess their microbiological and chemical characteristics.

\subsection{Influence of lactate-fermenting clostridia on Pannerone cheese quality}

To demonstrate the hypothesis that butyric acid is mainly produced by lactatefermenting clostridia, duplicate cheesemaking trials were undertaken in which lysozyme was added to milk at a rate of $50 \mathrm{mg} \cdot \mathrm{L}^{-1}$ (Chr. Hansen Ltd., Parma, Italy). The cheese was produced according to its traditional procedure and the curd was held at $30{ }^{\circ} \mathrm{C}$ for 6 days. Temperature and $\mathrm{pH}$ of cheese were monitored every $30 \mathrm{~min}$ and samples were analysed after 6 days to assess their chemical characteristics.

\subsection{Statistical analyses}

The chemical composition of cheese according to different warm room temperatures and lysozyme addition was analysed using one-way analysis of variance via Microsoft Office Excel 2003 (Microsoft Corp., USA). Differences between treatments were considered significant at the level of $P<0.05$. 
Table I. Microbiological characteristics $\left(\mathrm{CFU} \cdot \mathrm{g}^{-1}\right)$ of 26 samples of Pannerone cheese.

\begin{tabular}{|c|c|c|c|c|}
\hline Bacteria & Mean & $\mathrm{SE}^{\mathrm{a}}$ & Median & $\mathrm{SD}^{\mathrm{b}}$ \\
\hline Coliforms & $6.9 \times 10^{6}$ & $4.7 \times 10^{6}$ & $1.9 \times 10^{3}$ & $2.4 \times 10^{7}$ \\
\hline Escherichia coli & $4.5 \times 10^{6}$ & $4.0 \times 10^{6}$ & $3.7 \times 10^{4}$ & $2.1 \times 10^{7}$ \\
\hline Coagulase-positive staphylococci & $1.6 \times 10^{2}$ & $1.3 \times 10^{2}$ & $1.0 \times 10^{-1}$ & $6.8 \times 10^{2}$ \\
\hline Enterococci & $3.8 \times 10^{6}$ & $1.7 \times 10^{6}$ & $7.4 \times 10^{5}$ & $8.7 \times 10^{6}$ \\
\hline Cocci-shaped LAB & $7.9 \times 10^{7}$ & $3.1 \times 10^{7}$ & $2.5 \times 10^{7}$ & $1.6 \times 10^{8}$ \\
\hline Rod-shaped LAB & $1.7 \times 10^{8}$ & $5.3 \times 10^{7}$ & $1.2 \times 10^{8}$ & $2.7 \times 10^{8}$ \\
\hline Heterofermentative LAB & $2.1 \times 10^{7}$ & $1.1 \times 10^{7}$ & $1.0 \times 10^{7}$ & $5.5 \times 10^{7}$ \\
\hline Yeasts & $3.7 \times 10^{5}$ & $2.3 \times 10^{5}$ & $1.8 \times 10^{3}$ & $1.1 \times 10^{6}$ \\
\hline Moulds & $5.4 \times 10^{5}$ & $4.8 \times 10^{5}$ & $1.8 \times 10^{2}$ & $2.5 \times 10^{6}$ \\
\hline Lactate-fermenting clostridia spores & $1.9 \times 10^{5}$ & $8.9 \times 10^{4}$ & $1.6 \times 10^{4}$ & $4.0 \times 10^{5}$ \\
\hline Propionic acid bacteria & $9.0 \times 10^{5}$ & $5.3 \times 10^{5}$ & $3.6 \times 10^{5}$ & $2.1 \times 10^{6}$ \\
\hline Lipolytic bacteria & \multirow{2}{*}{\multicolumn{4}{|c|}{ Absent in $1 \mathrm{~g}$ sample }} \\
\hline Listeria monocytogenes & & & & \\
\hline Salmonella spp. & \multirow{2}{*}{\multicolumn{4}{|c|}{ Absent in $25 \mathrm{~g}$ sample }} \\
\hline E. coli $\mathrm{O} 157: \mathrm{H} 7$ & & & & \\
\hline
\end{tabular}

${ }^{a} \mathrm{SE}$, standard error.

${ }^{b} \mathrm{SD}$, standard deviation.

\section{RESULTS AND DISCUSSION}

\subsection{Microbiological characteristics of Pannerone cheese}

The microbiological analyses of 26 Pannerone cheeses (Tab. I) ready for consumption showed that pathogenic bacteria, i.e. Salmonella spp., L. monocytogenes and E. coli $\mathrm{O} 157: \mathrm{H} 7$, were absent. Forty-six E. coli strains isolated from six Pannerone cheeses of the present study were also studied by Zago et al. [30] to determine the presence of genes codifying for virulence factors. This study confirmed the absence of both O157:H7 and other enteropathogenic strains. Total coliforms were mostly $E$. coli, with median values, respectively, of $1.9 \times 10^{3}$ and $3.7 \times 10^{4} \mathrm{CFU} \cdot \mathrm{g}^{-1}$ but with a very large variability. This large variability is common in artisanal raw milk cheeses as described by Freitas and Malcata [13]. Coliforms were considered important for the sensorial properties of Pannerone cheese [23], because of their ability to produce gas and aromatic compounds such as formic and acetic acids, and 2,3-butanedione and to utilize citrate [9]. Counts of coagulase-positive staphylococci were usually low. The predominant microflora were LAB, mainly lactobacilli, present at levels of $10^{8} \mathrm{CFU} \cdot \mathrm{g}^{-1}$, while the counts of cocci were $1 \log$ lower. Among the other gas-producing bacteria that can be involved in the formation of the typical sponge-like structure of Pannerone cheese, heterofermentative LAB showed the highest counts, followed by $\mathrm{PAB}$ and lactate-fermenting clostridia spores, in that order (Tab. I). Yeasts, traditionally considered an important flora of Pannerone cheese [5, 23], showed a lower count than expected (mean value of $3.7 \times 10^{5} \mathrm{CFU} \cdot \mathrm{g}^{-1}$ and median value of $1.8 \times 10^{3} \mathrm{CFU} \cdot \mathrm{g}^{-1}$ ). No lipolytic bacteria were detected in Pannerone cheeses.

\subsection{Chemical composition of Pannerone cheese}

The mean chemical composition of Pannerone cheese (Tab. II) showed that total solids content $\left(592.3 \pm 9.4 \mathrm{~g} \cdot \mathrm{kg}^{-1}\right)$ of the 
Table II. Mean chemical composition $\left(\mathrm{g} \cdot \mathrm{kg}^{-1}\right)$ of 26 samples of Pannerone cheese.

\begin{tabular}{lcccc}
\hline & Mean & $\mathrm{SE}^{\mathrm{a}}$ & Median & $\mathrm{SD}^{\mathrm{b}}$ \\
\hline Total solids & 592.3 & 1.9 & 590.6 & 9.4 \\
Fat & 334.0 & 2.9 & 336.0 & 15.0 \\
Protein & 235.6 & 1.9 & 235.4 & 9.5 \\
Ash & 22.6 & 0.5 & 23.4 & 2.7 \\
Lactose & 0.00 & 0.00 & 0.00 & 0.00 \\
Galactose & 0.01 & 0.01 & 0.00 & 0.03 \\
Lactic acid & 1.27 & 0.35 & 0.74 & 1.79 \\
Acetic acid & 0.69 & 0.07 & 0.72 & 0.37 \\
Citric acid & 0.00 & 0.00 & 0.00 & 0.00 \\
Propionic acid & 1.71 & 0.10 & 1.77 & 0.50 \\
Butyric acid & 7.49 & 0.29 & 7.64 & 1.49 \\
pH & 5.61 & 0.03 & 5.59 & 0.13 \\
\hline
\end{tabular}

${ }^{\text {a }} \mathrm{SE}$, standard error.

${ }^{\mathrm{b}} \mathrm{SD}$, standard deviation.

cheeses were higher than the value of $500 \mathrm{~g} \cdot \mathrm{kg}^{-1}$ previously reported [26, 29], and similar to that reported for Pannerone cheese ripened for 30 days at a temperature ranging from 8 to $10^{\circ} \mathrm{C}$ instead of $4{ }^{\circ} \mathrm{C}$ [26]. Lactose, galactose and citric acid were detected but at negligible levels. The amount of lactic acid was very low $\left(1.27 \pm 1.79 \mathrm{~g} \cdot \mathrm{kg}^{-1}\right)$ in comparison to cheeses other than mould ripened cheeses [22], with an average $\mathrm{pH}$ value of 5.61. High amounts of butyric acid $\left(7.49 \pm 1.49 \mathrm{~g} \cdot \mathrm{kg}^{-1}\right)$ were detected. Butyric acid can be derived from lactate fermentation by butyric clostridia or from lipolysis, mainly by moulds or lamb paste rennet. Usually, butyric acid is present in cheese in lower amounts, even in defective cheeses such as hard cheeses cracked by an intensive late blowing. Bacci et al. [3] measured up to $1.8 \mathrm{~g} \cdot \mathrm{kg}^{-1}$ of butyric acid in blown Parmigiano Reggiano cheese. Experimental Emmental cheeses produced by adding Clostridium tyrobutyricum to milk had a butyric acid content of about $2.7 \mathrm{~g} \cdot \mathrm{kg}^{-1}$ [20]. Values of butyric acid similar to those measured in Pannerone were only found in a Turkish pickled white cheese after more than 6 months of ripening [2], but its origin was related to lipolysis. The amount of butyric acid in sheep raw milk Fiore Sardo cheese, obtained using lamb paste rennet ranged from 1.0 to $4.0 \mathrm{~g} \cdot \mathrm{kg}^{-1}[1,24]$. The butyric acid content was usually not higher than $2.6 \mathrm{~g} \cdot \mathrm{kg}^{-1}$ in Gorgonzola or other blue cheeses, produced with lipolytic Penicillium roqueforti as a starter [7, 10, 25]. In ripened Portuguese Serra ewe's cheese, the amount of butyric acid did not exceed $3.2 \pm 1.8 \mathrm{~g} \cdot \mathrm{kg}^{-1}$ [21].

The level of propionic acid of Pannerone cheese $\left(1.7 \pm 0.5 \mathrm{~g} \cdot \mathrm{kg}^{-1}\right.$, i.e. $4.2 \pm 1.2 \mathrm{~g} \cdot \mathrm{kg}^{-1}$ when calculated on its moisture basis) was lower than that of ripened Swiss cheese $\left(4.0-6.0 \mathrm{~g} \cdot \mathrm{kg}^{-1}\right.$ of cheese on moisture basis) [4] or Emmental Grand Cru cheeses $\left(8.0 \mathrm{~g} \cdot \mathrm{kg}^{-1}\right.$ in the extracted aqueous phase). This level is similar to that of Comté cheese $\left(4.9 \mathrm{~g} \cdot \mathrm{kg}^{-1}\right.$ in the extracted aqueous phase), but higher than that produced by $\mathrm{PAB}$ in some industrial French Emmental $\left(1.0-2.0 \mathrm{~g} \cdot \mathrm{kg}^{-1}\right.$ in the extracted aqueous phase) [28]. The amount of acetic acid of Pannerone (minimum $0.17 \mathrm{~g} \cdot \mathrm{kg}^{-1}$ and

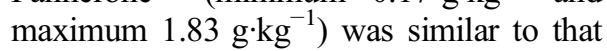


of other raw milk cheeses obtained without starter addition to milk, but significantly less than that recoverable in Emmental [28].

\subsection{Pannerone cheese technology}

Unrefrigerated raw milk was collected immediately after milking and transported to the dairy, where it was immediately transformed following the traditional technology (Tab. III) described by Savini [26] and Del Forno [11], with a few differences: a shorter renneting time (about $20 \mathrm{~min}$ compared to $45 \mathrm{~min}$ applied in the past [26]) and a shorter period in the warm room at $30{ }^{\circ} \mathrm{C}$ (6 days compared to $7-10$ days previously described $[11,26])$. Moreover, today the cheese is at retail within 1 week from cheese-making, while in the past the cheese was ripened at $8-10{ }^{\circ} \mathrm{C}$ for $8-10$ days and it was considered mature after 20 days [26].

\subsubsection{Monitoring of $\mathrm{pH}$, temperature, microbial counts and chemical composition during Pannerone cheese-making}

The changes of $\mathrm{pH}$ during the first 8 days from Pannerone cheese-making showed a specific behaviour (Fig. 1) characterized by a first phase where $\mathrm{pH}$ was substantially unchanged for $10 \mathrm{~h}$, followed by a sharp decrease to $\mathrm{pH} 5.1-5.2$ in the successive $10 \mathrm{~h}$. The drop in $\mathrm{pH}$ continued up to $48 \mathrm{~h}$ from cheese-making reaching a minimum value of 4.9 , and then the $\mathrm{pH}$ remained around that value for $40 \mathrm{~h}$. After the fourth day from cheese-making, the $\mathrm{pH}$ started to rise up to 5.7. The $\mathrm{pH}$ drop and the successive increase occurred because the temperature of the cheese $\left(28.4 \pm 1.4{ }^{\circ} \mathrm{C}\right)$ firstly remained favourable to the growth of LAB and then, when milk sugars had been depleted, the same high temperature allowed the growth of lactatefermenting bacteria, such as butyric clostridia and PAB.
The growth kinetics of the different microbial populations originating from raw milk and from the environment are summarized in Table IV. The lack of LAB starter was responsible for the delay in the start of acidification (Fig. 1). After 1 day from curd moulding, when the $\mathrm{pH}$ dropped to 5.1, cocci-shaped LAB were the most represented microflora, followed by total coliform bacteria. Heterofermentative LAB and enterococci grew at different speeds, according to the initial count in raw milk. $E$. coli reached their maximum values in the curd after 1 day (i.e. $10^{8} \mathrm{CFU} \cdot \mathrm{g}^{-1}$ ) and remained substantially stable up to 30 days of storage of the cheese at $4{ }^{\circ} \mathrm{C}$. Yeasts grew to $10^{5} \mathrm{CFU} \cdot \mathrm{g}^{-1}$. During the step in the warm room, the cheese temperature of about $28{ }^{\circ} \mathrm{C}$ allowed the growth of homofermentative LAB, mainly rod-shaped, to continue until there was a complete depletion of lactose, galactose and citric acid and a maximum production of lactic acid (Tab. V) and $\mathrm{pH}$ drop (Fig. 1). After the eighth day from cheese-making, the count of coagulase-positive staphylococci decreased. On the contrary, at the same time PAB started their growth reaching their maximum value after coming out of the warm room. The level of PAB was substantially unchanged during the storage of cheese at $4{ }^{\circ} \mathrm{C}$. The presence of the lactate-fermenting clostridia spores was detected only after more than 12 days from cheese-making, despite the large butyric acid amount present in the cheese after being in the warm room (Tab. V).

The growth kinetics of the different microbial groups are similar to those described previously by Ottogalli et al. [23], although they never found PAB and butyric clostridia in milk or in cheese. However, Bodini et al. [5] detected high levels of PAB both in the curd $\left(6.8 \times 10^{7} \mathrm{CFU} \cdot \mathrm{g}^{-1}\right)$ and in Pannerone cheese $\left(3.8 \times 10^{8} \mathrm{CFU} \cdot \mathrm{g}^{-1}\right)$.

The changes of the chemical composition of Pannerone cheese during the 
Table III. Pannerone cheese-making technology.

\begin{tabular}{|c|c|c|}
\hline & Mean & $\mathrm{SD}^{\mathrm{a}}$ \\
\hline Milk acidity in the vat $(\mathrm{pH})$ & 6.6 & 0.0 \\
\hline Temperature of milk in the vat $\left({ }^{\circ} \mathrm{C}\right)$ & 30.0 & 0.0 \\
\hline Starter addition & \multicolumn{2}{|c|}{ None } \\
\hline Liquid calf rennet ( $\mathrm{g} \cdot \mathrm{kg}^{-1}$ of milk) (chymosin minimum $70 \%$ ) & 0.04 & 0.0 \\
\hline Renneting time ( $\mathrm{min})$ & 20.2 & 4.0 \\
\hline Holding time between renneting and curd breaking - gel hardening (min) & 5.4 & 1.7 \\
\hline Time of curd breaking (min) & 20.2 & 7.5 \\
\hline Acidity of the whey at the curd extraction $\left({ }^{\circ} \mathrm{SH} / 50 \mathrm{~mL}\right)$ & 2.6 & 0.0 \\
\hline Curd extraction from the vat & \multicolumn{2}{|c|}{$\begin{array}{c}\text { By means of linen cloths, each } \\
\text { containing about } 6 \mathrm{~kg} \text { of curd, forming } \\
\text { bundles superimposed one on top } \\
\text { of the other }\end{array}$} \\
\hline Time used for curd extraction by hand with linen cloths ( $\min$ ) & 15.7 & 2.6 \\
\hline Temperature of the extracted curd $\left({ }^{\circ} \mathrm{C}\right)$ & 27.3 & 0.5 \\
\hline $\begin{array}{l}\text { Holding time of the curd in cloths for the first whey drainage, before transport in another } \\
\text { room for the } 2^{\text {nd }} \text { drainage ( } \mathrm{min} \text { ) }\end{array}$ & 9.7 & 4.1 \\
\hline Holding time of the curd before moulding (min) & 23.7 & 5.7 \\
\hline Time used for curd milling by hand and moulding ( $\mathrm{min})$ & 13.3 & 2.9 \\
\hline Temperature of the curd in the mould $\left({ }^{\circ} \mathrm{C}\right)$ & 25.2 & 0.4 \\
\hline Holding time of the moulded curd in the room for the $2^{\text {nd }}$ whey drainage $(\mathrm{h})$ & 11.6 & 1.2 \\
\hline Temperature of the curd at the end of the holding time $\left({ }^{\circ} \mathrm{C}\right)$ before the entry in warm room & 27.7 & 1.5 \\
\hline Temperature of the warm room $\left({ }^{\circ} \mathrm{C}\right)$ & 29.8 & 0.8 \\
\hline Temperature of the curd after $48 \mathrm{~h}$ of rest in warm room $\left({ }^{\circ} \mathrm{C}\right)$ & 29.5 & 0.6 \\
\hline Extraction of the curd from the mould and wrapping with a wooden band & \multicolumn{2}{|c|}{ Usually after $48 \mathrm{~h}$ in warm room } \\
\hline Holding time in the warm room $(\mathrm{h})$ cheese wheels are turned upside down & 111.4 & 14.1 \\
\hline & \multicolumn{2}{|c|}{ Every day } \\
\hline Temperature of Pannerone cheese at the exit from the warm room $\left({ }^{\circ} \mathrm{C}\right)$ & 27.6 & 1.1 \\
\hline Temperature of the room for the pre-cooling of the cheese $\left({ }^{\circ} \mathrm{C}\right)$ & 18.2 & 1.5 \\
\hline Holding time for the pre-cooling step $(\mathrm{h})$ & 14.4 & 6.4 \\
\hline Temperature of Pannerone cheese at the end of pre-cooling $\left({ }^{\circ} \mathrm{C}\right)$ & 18.2 & 1.7 \\
\hline Holding time in refrigerated room at $5 \pm 1{ }^{\circ} \mathrm{C}(\mathrm{h})$ & 20.9 & 6.4 \\
\hline Salting of Pannerone (brining/dry) & \multicolumn{2}{|c|}{ None } \\
\hline Storing of the cheese in the warehouse of the dairy at $6 \pm 1{ }^{\circ} \mathrm{C}$ & \multirow{2}{*}{\multicolumn{2}{|c|}{$<1$ week }} \\
\hline Shelf life & & \\
\hline
\end{tabular}

${ }^{a} \mathrm{SD}$, standard deviation. 


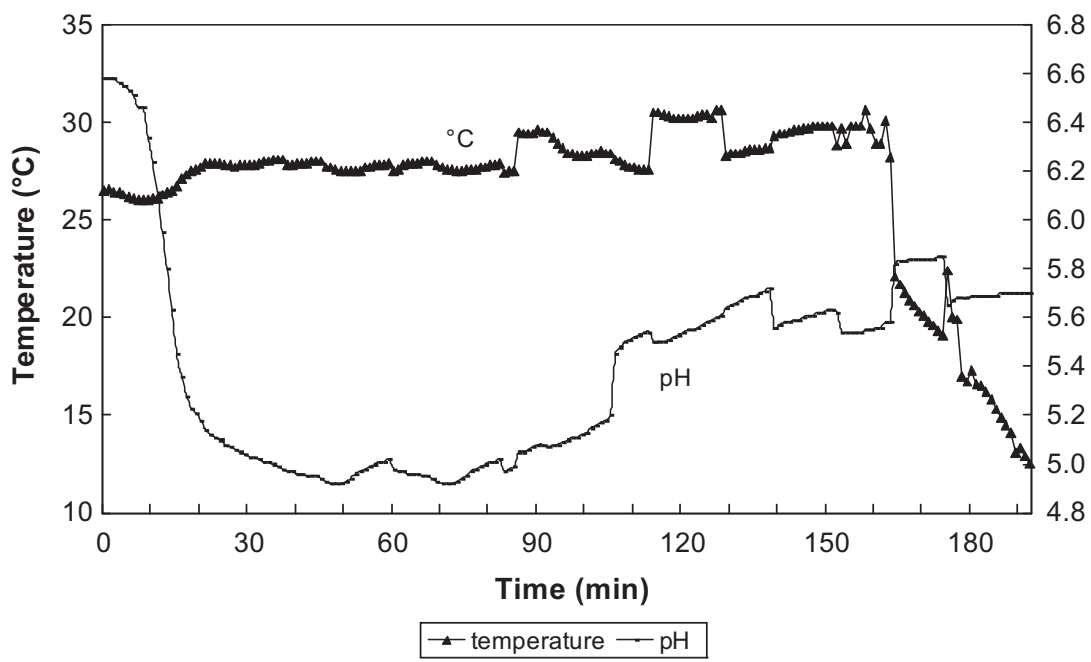

Figure 1. Evolution of temperature and $\mathrm{pH}$ during the first 8 days from cheese-making. Note: The fluctuations of $\mathrm{pH}$ and temperature values, mainly after the fourth day, correspond to the different positions of the probes when the cheese was turned upside down.

cheese-making and shelf life are summarized in Table V. The balance between lactose, galactose and lactic acid showed fast depletion of lactose and galactose by the fourth day from cheese-making and increase of lactic acid up to $15 \mathrm{~g} \cdot \mathrm{kg}^{-1}$. By the end of the warm room time, on the eighth day, citric acid was totally consumed, lactates were progressively metabolized to $<2 \mathrm{~g} \cdot \mathrm{kg}^{-1}$ and the maximum production of butyric and propionic acids was observed. Lactate utilization was concomitant with increase in the $\mathrm{pH}$ of the cheese to values higher than 5.45 (Fig. 1). Acetic acid concentration showed a more complicated behaviour: it reached a maximum value during the warm room step, corresponding to the maximum growth of heterofermentative LAB and coliforms, then it decreased concurrently to butyric acid production, and finally it increased a second time. Differently from the other works on Pannerone cheese that underlined the importance of heterofermentative LAB and coliforms [5, 23], our data demonstrate that there was a fundamental role played by the lactate metabolism, and specifically by the lactate-fermenting bacteria, mainly butyric clostridia [18], whose growth was favoured by the maintenance of the cheese at $30{ }^{\circ} \mathrm{C}$.

\subsubsection{Influence of the warm room step on Pannerone cheese quality}

While Swiss-type cheeses are usually kept at warm room temperatures $\left(22-24{ }^{\circ} \mathrm{C}\right)$ after brining to enable the propionic fermentation [19], prolonged holding of unsalted curd at similar or higher temperatures is typical of few raw milk cheeses, among them Pannerone and Castelmagno. After extraction from the cheese vat the curd of Castelmagno is cut into large pieces and dipped into whey at room temperature up to 6 days, then it is milled, dry salted and moulded $[12,22]$. To demonstrate that the specific time and temperature combination applied in the warm room is essential for Pannerone cheese, incubation trials were performed 
Table IV. Microbial population changes $\left(\mathrm{CFU} \cdot \mathrm{g}^{-1}\right)$ during traditional Pannerone cheese production and storage. Trials were performed in duplicate.

\begin{tabular}{|c|c|c|c|c|c|c|c|c|}
\hline \multirow[t]{3}{*}{ Bacteria } & & \multirow[t]{3}{*}{ Milk } & \multirow[b]{3}{*}{ Before moulding } & \multicolumn{5}{|c|}{ Cheese } \\
\hline & & & & \multicolumn{3}{|c|}{ Warm room at $30^{\circ} \mathrm{C}$} & \multicolumn{2}{|c|}{ Storage at $4{ }^{\circ} \mathrm{C}$} \\
\hline & & & & 1 day & 4 days & 8 days & 12 days & 30 days \\
\hline \multirow[t]{2}{*}{ Coliforms } & Mean & $7.2 \times 10^{2}$ & $3.6 \times 10^{3}$ & $2.6 \times 10^{7}$ & $4.0 \times 10^{4}$ & $1.4 \times 10^{4}$ & $1.0 \times 10^{4}$ & $1.0 \times 10^{1}$ \\
\hline & $\mathrm{SD}^{\mathrm{a}}$ & $8.7 \times 10^{2}$ & $9.1 \times 10^{3}$ & $3.7 \times 10^{7}$ & $6.5 \times 10^{5}$ & $1.2 \times 10^{6}$ & $1.3 \times 10^{5}$ & $9.5 \times 10^{4}$ \\
\hline \multirow[t]{2}{*}{ E. coli } & Mean & $2.0 \times 10^{2}$ & $5.0 \times 10^{1}$ & $2.9 \times 10^{5}$ & $1.7 \times 10^{5}$ & $1.5 \times 10^{5}$ & $5.0 \times 10^{4}$ & $7.3 \times 10^{4}$ \\
\hline & SD & $1.4 \times 10^{2}$ & $1.4 \times 10^{4}$ & $3.4 \times 10^{5}$ & $4.7 \times 10^{5}$ & $9.8 \times 10^{4}$ & $7.8 \times 10^{4}$ & $1.5 \times 10^{5}$ \\
\hline \multirow[t]{2}{*}{ Coagulase-positive staphylococci } & Mean & $1.5 \times 10^{2}$ & $1.5 \times 10^{2}$ & $6.9 \times 10^{4}$ & $8.8 \times 10^{3}$ & $1.0 \times 10^{2}$ & $1.0 \times 10^{1}$ & $1.0 \times 10^{1}$ \\
\hline & SD & $2.0 \times 10^{2}$ & $1.3 \times 10^{4}$ & $6.8 \times 10^{4}$ & $1.4 \times 10^{4}$ & $6.4 \times 10^{2}$ & $6.0 \times 10^{2}$ & $1.3 \times 10^{1}$ \\
\hline \multirow[t]{2}{*}{ Enterococci } & Mean & $1.7 \times 10^{1}$ & $1.3 \times 10^{3}$ & $2.8 \times 10^{5}$ & $5.5 \times 10^{5}$ & $1.1 \times 10^{6}$ & $1.4 \times 10^{6}$ & $2.5 \times 10^{5}$ \\
\hline & SD & $4.7 \times 10^{2}$ & $1.2 \times 10^{4}$ & $4.3 \times 10^{6}$ & $6.4 \times 10^{6}$ & $3.0 \times 10^{7}$ & $4.5 \times 10^{7}$ & $4.3 \times 10^{6}$ \\
\hline \multirow[t]{2}{*}{ Cocci-shaped LAB } & Mean & $1.2 \times 10^{4}$ & $2.4 \times 10^{5}$ & $4.7 \times 10^{8}$ & $1.2 \times 10^{9}$ & $3.5 \times 10^{8}$ & $1.7 \times 10^{8}$ & $2.0 \times 10^{7}$ \\
\hline & SD & $8.2 \times 10^{5}$ & $1.1 \times 10^{8}$ & $1.4 \times 10^{9}$ & $1.4 \times 10^{9}$ & $8.9 \times 10^{7}$ & $8.5 \times 10^{8}$ & $6.0 \times 10^{7}$ \\
\hline \multirow[t]{2}{*}{ Rod-shaped LAB } & Mean & $4.5 \times 10^{3}$ & $1.2 \times 10^{4}$ & $6.7 \times 10^{5}$ & $1.8 \times 10^{8}$ & $1.9 \times 10^{8}$ & $1.2 \times 10^{8}$ & $1.1 \times 10^{7}$ \\
\hline & SD & $6.1 \times 10^{3}$ & $1.5 \times 10^{4}$ & $2.1 \times 10^{6}$ & $1.7 \times 10^{7}$ & $1.1 \times 10^{8}$ & $4.2 \times 10^{7}$ & $2.5 \times 10^{8}$ \\
\hline \multirow[t]{2}{*}{ Heterofermentative LAB } & Mean & $1.0 \times 10^{4}$ & $1.0 \times 10^{5}$ & $1.0 \times 10^{7}$ & $1.0 \times 10^{7}$ & $1.0 \times 10^{7}$ & $1.0 \times 10^{7}$ & $1.0 \times 10^{6}$ \\
\hline & SD & $1.2 \times 10^{4}$ & $1.3 \times 10^{5}$ & $1.4 \times 10^{7}$ & $1.1 \times 10^{7}$ & $1.3 \times 10^{7}$ & $4.2 \times 10^{7}$ & $5.7 \times 10^{6}$ \\
\hline \multirow[t]{2}{*}{ Lactate-fermenting clostridia spores } & Mean & $2.4 \times 10^{2}$ & $3.6 \times 10^{0}$ & $3.6 \times 10^{0}$ & $2.3 \times 10^{1}$ & $2.3 \times 10^{1}$ & $7.5 \times 10^{1}$ & $2.1 \times 10^{4}$ \\
\hline & SD & $3.4 \times 10^{2}$ & $3.8 \times 10^{0}$ & $7.9 \times 10^{0}$ & $0.0 \times 10^{0}$ & $6.2 \times 10^{2}$ & $2.9 \times 10^{2}$ & $2.1 \times 10^{4}$ \\
\hline \multirow[t]{2}{*}{ Propionic acid bacteria } & Mean & $3.0 \times 10^{1}$ & $1.0 \times 10^{3}$ & $\mathrm{nd}^{\mathrm{b}}$ & $7.0 \times 10^{3}$ & nd & nd & $1.9 \times 10^{6}$ \\
\hline & SD & $4.1 \times 10^{1}$ & $1.4 \times 10^{3}$ & - & $9.9 \times 10^{3}$ & - & - & $2.0 \times 10^{6}$ \\
\hline \multirow[t]{2}{*}{ Yeasts } & Mean & $3.5 \times 10^{3}$ & $1.4 \times 10^{4}$ & $2.6 \times 10^{5}$ & $4.4 \times 10^{5}$ & $9.7 \times 10^{5}$ & $3.0 \times 10^{6}$ & $2.6 \times 10^{5}$ \\
\hline & SD & $1.8 \times 10^{3}$ & $1.3 \times 10^{3}$ & $5.2 \times 10^{5}$ & $3.8 \times 10^{5}$ & $1.3 \times 10^{6}$ & $4.2 \times 10^{6}$ & $3.5 \times 10^{5}$ \\
\hline \multirow[t]{2}{*}{ Moulds } & Mean & $4.8 \times 10^{2}$ & $1.4 \times 10^{3}$ & $3.5 \times 10^{2}$ & $6.0 \times 10^{4}$ & $5.0 \times 10^{4}$ & $4.1 \times 10^{5}$ & $2.6 \times 10^{5}$ \\
\hline & SD & $4.7 \times 10^{2}$ & $1.1 \times 10^{3}$ & $2.3 \times 10^{4}$ & $3.5 \times 10^{4}$ & $8.5 \times 10^{3}$ & $4.7 \times 10^{5}$ & $3.6 \times 10^{5}$ \\
\hline Lipolytic bacteria & \multicolumn{8}{|c|}{ Not detected in $1 \mathrm{~g}$ of cheese } \\
\hline
\end{tabular}

\footnotetext{
${ }^{\text {a }} \mathrm{SD}$, standard deviation.
}

${ }^{b}$ nd, not determined. 
Table V. Chemical composition $\left(\mathrm{g} \cdot \mathrm{kg}^{-1}\right)$ during traditional Pannerone cheese production and storage. Trials were performed in duplicate.

\begin{tabular}{|c|c|c|c|c|c|c|c|c|}
\hline & & \multirow[t]{3}{*}{ Milk } & \multirow{3}{*}{$\begin{array}{c}\text { Curd } \\
\text { Before moulding }\end{array}$} & \multicolumn{5}{|c|}{ Cheese } \\
\hline & & & & \multicolumn{3}{|c|}{ Warm room at $30^{\circ} \mathrm{C}$} & \multicolumn{2}{|c|}{ Storage at $4{ }^{\circ} \mathrm{C}$} \\
\hline & & & & 1 day & 4 days & 8 days & 12 days & 30 days \\
\hline \multirow[t]{2}{*}{$\mathrm{pH}$} & Mean & 6.60 & 6.55 & 5.18 & 5.10 & 5.70 & 5.69 & 5.68 \\
\hline & $\mathrm{SD}^{\mathrm{a}}$ & 0.01 & 0.02 & 0.04 & 0.03 & 0.06 & 0.04 & 0.05 \\
\hline \multirow[t]{2}{*}{ Total solids } & Mean & 130.4 & 461.5 & 516.1 & 572.5 & 579.9 & 588.6 & 609.4 \\
\hline & SD & 5.8 & 43.7 & 23.5 & 3.2 & 0.7 & 2.1 & 10.1 \\
\hline \multirow[t]{2}{*}{ Lactose } & Mean & 52.58 & 27.42 & 13.20 & 0.00 & 0.00 & 0.00 & 0.00 \\
\hline & $\mathrm{SD}$ & 3.07 & 1.94 & 0.94 & 0.00 & 0.00 & 0.00 & 0.00 \\
\hline \multirow{2}{*}{ Citric acid } & Mean & 1.82 & 1.80 & 1.59 & 0.31 & 0.00 & 0.00 & 0.00 \\
\hline & $\mathrm{SD}$ & 0.21 & 0.29 & 1.07 & 0.22 & 0.00 & 0.00 & 0.00 \\
\hline \multirow[t]{2}{*}{ Galactose } & Mean & 0.00 & 0.02 & 0.17 & 0.00 & 0.00 & 0.00 & 0.00 \\
\hline & SD & 0.08 & 0.02 & 0.02 & 0.09 & 0.03 & 0.08 & 0.04 \\
\hline \multirow[t]{2}{*}{ Lactic acid } & Mean & 0.00 & 0.14 & 6.74 & 15.03 & 1.04 & 1.24 & 1.12 \\
\hline & $\mathrm{SD}$ & 0.00 & 0.10 & 1.94 & 0.01 & 4.38 & 4.47 & 3.72 \\
\hline \multirow[t]{2}{*}{ Acetic acid } & Mean & 0.00 & 0.00 & 0.41 & 1.16 & 0.33 & 0.48 & 0.83 \\
\hline & $\mathrm{SD}$ & 0.00 & 0.00 & 0.54 & 0.34 & 0.16 & 0.28 & 0.71 \\
\hline \multirow[t]{2}{*}{ Propionic acid } & Mean & 0.00 & 0.00 & 0.00 & 0.24 & 1.75 & 1.57 & 1.61 \\
\hline & $\mathrm{SD}$ & 0.00 & 0.00 & 0.10 & 0.07 & 0.16 & 0.12 & 0.05 \\
\hline \multirow{2}{*}{ Butyric acid } & Mean & 0.00 & 0.25 & 0.24 & 0.92 & 8.12 & 7.66 & 7.53 \\
\hline & $\mathrm{SD}$ & 0.00 & 0.18 & 0.01 & 0.38 & 1.36 & 0.89 & 0.61 \\
\hline
\end{tabular}

${ }^{a} \mathrm{SD}$, standard deviation. 


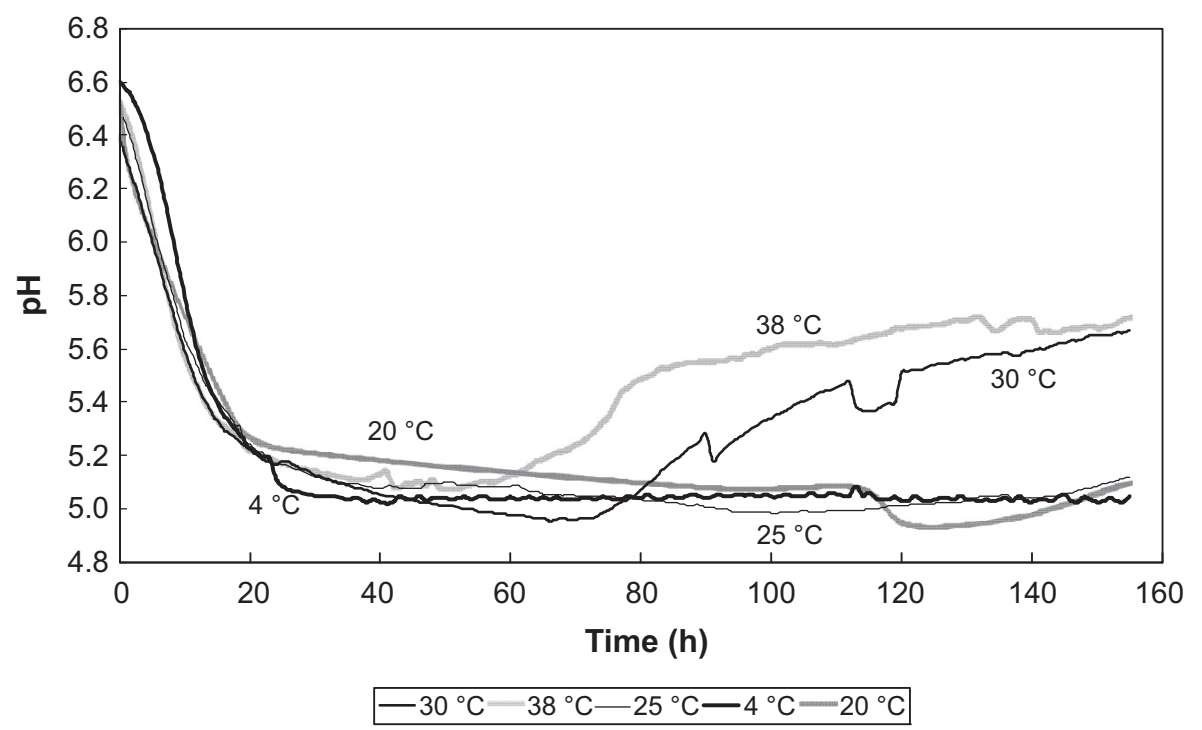

Figure 2. Evolution of $\mathrm{pH}$ during the first 6 days from cheese-making of experimental Pannerone cheeses incubated at $4,20,25,30$ (control) and $38{ }^{\circ} \mathrm{C}$.

changing the temperature of the warm room. The curd, obtained on different days always using the same cheese-making technology, remained for about $7 \mathrm{~h}$ at a room temperature of $26{ }^{\circ} \mathrm{C}$ to allow as much draining of the whey as possible. Then the moulds were stored at different air temperatures $(4,20$, 25 and 30 as control and $38^{\circ} \mathrm{C}$ ) for 6 days. Before incubating at $4{ }^{\circ} \mathrm{C}$, the curd was kept at $30{ }^{\circ} \mathrm{C}$ for $32 \mathrm{~h}$ to allow lactic acid fermentation. The temperature of the curds reached equilibrium with the room temperature within $24 \mathrm{~h}$ from the start of the incubation. The $\mathrm{pH}$ dropped to about 4.95 (Fig. 2) within the first $60 \mathrm{~h}$ and the rate of acidification was substantially the same, in spite of the different temperatures. After this time, the $\mathrm{pH}$ changed greatly according to temperature: the $\mathrm{pH}$ increased to 5.5 or even to higher values when the cheese was stored at 30 or $38^{\circ} \mathrm{C}$. When the cheese was incubated at $4{ }^{\circ} \mathrm{C}$, the usual ripening temperature for Italian soft or semi-soft cheeses that are not mould surface ripened, like Crescenza, Quartirolo or Italico cheeses [22], the $\mathrm{pH}$ did not increase. Cheese stored at 30 and $38{ }^{\circ} \mathrm{C}$ showed a significant $\mathrm{pH}$ increase compared to that observed at lower temperature. The higher $\mathrm{pH}$ values after 6 days corresponded to significant lower lactic acid and to higher propionic and butyric acid contents (Tab. VI).

The amounts of residual lactose, galactose and lactic acid after the first day from cheese-making were not significantly different in all the curds. Acetic acid was present at levels of about $1 \mathrm{~g} \cdot \mathrm{kg}^{-1}$, probably produced by the high number of coliform bacteria [9] (Tab. VII). Propionic and butyric acids were detected, but in small amounts. After 6 days, lactose was depleted in all the cheeses with the exception of that stored at $4{ }^{\circ} \mathrm{C}$, and galactose was still present in traces. The concentration of lactic acid was inversely correlated to the temperature of the warm room, while that of propionic and butyric acids was positively correlated 
Table VI. Chemical composition $\left(\mathrm{g} \cdot \mathrm{kg}^{-1}\right)$ of Pannerone cheese after 1 day and 6 days of storage at different temperatures. Number of trials at temperature of $4,20,25,30$ and $38^{\circ} \mathrm{C}$ were respectively $3,3,5,3$ and 3 .

\begin{tabular}{|c|c|c|c|c|c|c|c|c|c|c|}
\hline & \multicolumn{2}{|c|}{$4^{\circ} \mathrm{C}$} & \multicolumn{2}{|c|}{$20^{\circ} \mathrm{C}$} & \multicolumn{2}{|c|}{$25^{\circ} \mathrm{C}$} & \multicolumn{2}{|c|}{$30^{\circ} \mathrm{C}$} & \multicolumn{2}{|c|}{$38^{\circ} \mathrm{C}$} \\
\hline & Mean & SD & Mean & SD & Mean & SD & Mean & SD & Mean & SD \\
\hline \multicolumn{11}{|l|}{1 day } \\
\hline Total solids & $510.2^{\mathrm{a}}$ & 3.1 & $516.5^{\mathrm{a}}$ & 3.0 & $512.4^{\mathrm{a}}$ & 19.7 & $540.5^{\mathrm{b}}$ & 12.5 & $574.8^{\mathrm{b}}$ & 12.5 \\
\hline Lactose & 11.40 & 0.42 & 8.45 & 3.46 & 11.88 & 2.42 & 11.10 & 4.81 & 6.85 & 2.19 \\
\hline Galactose & 0.30 & 0.00 & 0.20 & 0.14 & 0.25 & 0.06 & 0.15 & 0.07 & 0.30 & 0.14 \\
\hline Lactic acid & 8.75 & 1.20 & 7.50 & 1.13 & 7.70 & 1.51 & 6.80 & 3.96 & 7.90 & 0.99 \\
\hline Acetic acid & 0.75 & 0.35 & 1.10 & 0.14 & 1.03 & 0.37 & 1.20 & 0.00 & 1.20 & 0.28 \\
\hline Citric acid & 0.60 & 0.85 & 0.00 & 0.00 & 0.30 & 0.60 & 0.05 & 0.07 & 0.00 & 0.00 \\
\hline Propionic acid & 0.20 & 0.14 & 0.20 & 0.14 & 0.10 & 0.08 & 0.20 & 0.14 & 0.10 & 0.14 \\
\hline Butyric acid & 0.05 & 0.07 & 0.20 & 0.14 & 0.28 & 0.24 & 0.25 & 0.07 & 0.30 & 0.42 \\
\hline $\mathrm{pH}$ & 5.24 & 0.04 & 5.27 & 0.07 & 5.26 & 0.06 & 5.22 & 0.05 & 5.27 & 0.01 \\
\hline \multicolumn{11}{|l|}{6 days } \\
\hline Total solids & $546.1^{\mathrm{a}}$ & 7.1 & $552.9^{\mathrm{a}}$ & 5.9 & $566.5^{\mathrm{b}}$ & 11.0 & $579.8^{\mathrm{b}}$ & 2.0 & $598.0^{\mathrm{c}}$ & 9.5 \\
\hline Lactose & $4.05^{\mathrm{a}}$ & 0.49 & $0.00^{\mathrm{b}}$ & 0.00 & $0.00^{\mathrm{b}}$ & 0.00 & $0.00^{\mathrm{b}}$ & 0.00 & $0.00^{\mathrm{b}}$ & 0.00 \\
\hline Galactose & 0.30 & 0.14 & 0.17 & 0.06 & 0.15 & 0.08 & 0.07 & 0.06 & 0.00 & 0.00 \\
\hline Lactic acid & $13.15^{\mathrm{a}}$ & 1.20 & $15.27^{\mathrm{a}}$ & 1.58 & $9.40^{\mathrm{a}}$ & 5.09 & $3.09^{\mathrm{b}}$ & 1.84 & $0.60^{\mathrm{c}}$ & 0.51 \\
\hline Acetic acid & $0.90^{\mathrm{a}}$ & 0.28 & $0.90^{\mathrm{a}}$ & 0.26 & $0.81^{\mathrm{a}}$ & 0.48 & $0.40^{\mathrm{b}}$ & 0.17 & $0.29^{\mathrm{b}}$ & 0.12 \\
\hline Citric acid & $0.60^{\mathrm{a}}$ & 0.85 & $0.00^{\mathrm{b}}$ & 0.00 & $0.00^{\mathrm{b}}$ & 0.00 & $0.00^{\mathrm{b}}$ & 0.00 & $0.00^{\mathrm{b}}$ & 0.00 \\
\hline Propionic acid & $0.10^{\mathrm{a}}$ & 0.14 & $0.30^{\mathrm{a}}$ & 0.10 & $0.71^{\mathrm{a}}$ & 0.73 & $1.27^{\mathrm{b}}$ & 0.51 & $1.61^{\mathrm{b}}$ & 0.50 \\
\hline Butyric acid & $0.35^{\mathrm{a}}$ & 0.07 & $1.14^{\mathrm{b}}$ & 0.37 & $3.43^{b}$ & 2.60 & $6.29^{c}$ & 1.21 & $6.40^{\mathrm{c}}$ & 1.18 \\
\hline $\mathrm{pH}$ & $5.28^{\mathrm{a}}$ & 0.25 & $5.27^{\mathrm{a}}$ & 0.08 & $5.36^{\mathrm{a}}$ & 0.36 & $5.69^{\mathrm{b}}$ & 0.10 & $5.72^{\mathrm{b}}$ & 0.08 \\
\hline
\end{tabular}

a, b, c Different letters in the same row mean that the values are significantly different $(P<0.05)$.

Rows without superscripts did not present significant differences. 
Table VII. Microbial counts $\left(\mathrm{CFU} \cdot \mathrm{g}^{-1}\right)$ of Pannerone cheese after 1 day and 6 days of storage at different temperatures. Number of trials at temperature of $4,20,25,30$ and $38^{\circ} \mathrm{C}$ were respectively $3,3,5,3$ and 3 .

\begin{tabular}{|c|c|c|c|c|c|c|c|c|c|c|c|c|}
\hline \multirow[t]{2}{*}{ Bacteria } & \multicolumn{2}{|c|}{$4^{\circ} \mathrm{C}$} & \multicolumn{2}{|c|}{$20{ }^{\circ} \mathrm{C}$} & \multicolumn{3}{|c|}{$25^{\circ} \mathrm{C}$} & \multicolumn{3}{|c|}{$30{ }^{\circ} \mathrm{C}$} & \multicolumn{2}{|c|}{$38^{\circ} \mathrm{C}$} \\
\hline & Mean $^{*}$ & $\mathrm{SD}^{\mathrm{a}}$ & Mean ${ }^{*}$ & SD & Mean & Median & SD & Mean & Median & SD & Mean ${ }^{*}$ & SD \\
\hline \multicolumn{13}{|l|}{1 day } \\
\hline Coliforms & $3.3 \times 10^{7}$ & $2.2 \times 10^{7}$ & $9.8 \times 10^{7}$ & $8.2 \times 10^{7}$ & $1.2 \times 10^{8}$ & $1.3 \times 10^{8}$ & $5.0 \times 10^{7}$ & $1.8 \times 10^{8}$ & $8.2 \times 10^{7}$ & $2.4 \times 10^{8}$ & $9.6 \times 10^{7}$ & $4.0 \times 10^{7}$ \\
\hline E. coli & $9.8 \times 10^{5}$ & $7.4 \times 10^{5}$ & $3.6 \times 10^{8}$ & $5.0 \times 10^{8}$ & $1.3 \times 10^{7}$ & $3.3 \times 10^{6}$ & $2.2 \times 10^{7}$ & $1.3 \times 10^{8}$ & $1.3 \times 10^{6}$ & $2.6 \times 10^{8}$ & $2.6 \times 10^{7}$ & $3.6 \times 10^{7}$ \\
\hline $\begin{array}{l}\text { Coagulase-positive } \\
\text { staphylococci }\end{array}$ & $5.1 \times 10^{2}$ & $7.0 \times 10^{2}$ & $1.1 \times 10^{4}$ & $1.4 \times 10^{4}$ & $1.7 \times 10^{6}$ & $1.1 \times 10^{5}$ & $3.3 \times 10^{6}$ & $5.9 \times 10^{3}$ & $1.4 \times 10^{3}$ & $1.0 \times 10^{4}$ & $4.3 \times 10^{6}$ & $5.7 \times 10^{6}$ \\
\hline Cocci-shaped LAB & $2.4 \times 10^{8}$ & $3.4 \times 10^{8}$ & $1.1 \times 10^{9}$ & $3.9 \times 10^{8}$ & $9.9 \times 10^{8}$ & $8.9 \times 10^{8}$ & $6.5 \times 10^{8}$ & $6.8 \times 10^{8}$ & $6.3 \times 10^{8}$ & $6.0 \times 10^{8}$ & $6.0 \times 10^{8}$ & $8.8 \times 10^{7}$ \\
\hline Rod-shaped LAB & $4.1 \times 10^{4}$ & $5.5 \times 10^{4}$ & $1.6 \times 10^{6}$ & $2.1 \times 10^{6}$ & $1.7 \times 10^{5}$ & $1.2 \times 10^{5}$ & $1.3 \times 10^{5}$ & $6.4 \times 10^{5}$ & $1.9 \times 10^{5}$ & $1.0 \times 10^{6}$ & $2.1 \times 10^{6}$ & $2.9 \times 10^{6}$ \\
\hline $\begin{array}{l}\text { Heterofermentative } \\
\text { LAB }\end{array}$ & $1.0 \times 10^{4}$ & $0.0 \times 10^{0}$ & $4.1 \times 10^{5}$ & $5.6 \times 10^{5}$ & $2.8 \times 10^{6}$ & $5.5 \times 10^{5}$ & $4.8 \times 10^{6}$ & $4.6 \times 10^{5}$ & $2.5 \times 10^{5}$ & $6.2 \times 10^{5}$ & $5.1 \times 10^{6}$ & $7.0 \times 10^{6}$ \\
\hline Yeasts & $1.6 \times 10^{5}$ & $6.0 \times 10^{4}$ & $7.0 \times 10^{6}$ & $7.9 \times 10^{6}$ & $4.6 \times 10^{5}$ & $3.4 \times 10^{4}$ & $8.7 \times 10^{5}$ & $3.7 \times 10^{6}$ & $4.2 \times 10^{5}$ & $6.8 \times 10^{6}$ & $4.0 \times 10^{4}$ & $2.7 \times 10^{4}$ \\
\hline Moulds & $1.0 \times 10^{3}$ & $0.0 \times 10^{0}$ & $1.3 \times 10^{2}$ & $3.5 \times 10^{1}$ & $1.3 \times 10^{2}$ & $1.0 \times 10^{2}$ & $5.8 \times 10^{1}$ & $4.2 \times 10^{3}$ & $1.0 \times 10^{2}$ & $8.3 \times 10^{3}$ & $5.5 \times 10^{1}$ & $6.4 \times 10^{1}$ \\
\hline $\begin{array}{l}\text { Lactate-fermenting } \\
\text { clostridia spores }\end{array}$ & $7.0 \times 10^{0}$ & $5.7 \times 10^{0}$ & $2.3 \times 10^{0}$ & $1.8 \times 10^{0}$ & $1.0 \times 10^{0}$ & $1.0 \times 10^{0}$ & $0.0 \times 10^{0}$ & $5.6 \times 10^{0}$ & $5.1 \times 10^{0}$ & $5.3 \times 10^{0}$ & $2.3 \times 10^{0}$ & $1.8 \times 10^{0}$ \\
\hline $\begin{array}{l}\text { Propionic acid } \\
\text { bacteria }\end{array}$ & $1.3 \times 10^{3}$ & $4.2 \times 10^{2}$ & $1.4 \times 10^{3}$ & $2.0 \times 10^{3}$ & $1.5 \times 10^{3}$ & $9.0 \times 10^{2}$ & $1.7 \times 10^{3}$ & $1.1 \times 10^{3}$ & $8.5 \times 10^{2}$ & $1.2 \times 10^{3}$ & $4.0 \times 10^{3}$ & $4.5 \times 10^{3}$ \\
\hline \multicolumn{13}{|l|}{6 days } \\
\hline Coliforms & $4.1 \times 10^{7}$ & $5.2 \times 10^{7}$ & $2.6 \times 10^{7}$ & $2.5 \times 10^{7}$ & $4.9 \times 10^{5}$ & $4.9 \times 10^{5}$ & $2.8 \times 10^{5}$ & $4.2 \times 10^{7}$ & $4.1 \times 10^{7}$ & $4.6 \times 10^{7}$ & $5.1 \times 10^{1}$ & $7.0 \times 10^{1}$ \\
\hline E. coli & $1.2 \times 10^{6}$ & $1.1 \times 10^{6}$ & $2.2 \times 10^{7}$ & $3.1 \times 10^{7}$ & $2.4 \times 10^{7}$ & $2.0 \times 10^{6}$ & $4.5 \times 10^{7}$ & $2.2 \times 10^{7}$ & $1.2 \times 10^{6}$ & $4.2 \times 10^{7}$ & $8.5 \times 10^{1}$ & $2.1 \times 10^{1}$ \\
\hline $\begin{array}{l}\text { Coagulase-positive } \\
\text { staphylococci }\end{array}$ & $1.4 \times 10^{7}$ & $1.9 \times 10^{7}$ & $1.4 \times 10^{4}$ & $1.6 \times 10^{4}$ & $1.7 \times 10^{6}$ & $9.4 \times 10^{5}$ & $1.9 \times 10^{6}$ & $6.9 \times 10^{6}$ & $7.8 \times 10^{2}$ & $1.4 \times 10^{7}$ & $5.1 \times 10^{1}$ & $7.0 \times 10^{1}$ \\
\hline Cocci-shaped LAB & $1.3 \times 10^{9}$ & $5.6 \times 10^{8}$ & $6.3 \times 10^{8}$ & $8.7 \times 10^{8}$ & $6.3 \times 10^{8}$ & $5.9 \times 10^{8}$ & $2.6 \times 10^{8}$ & $8.8 \times 10^{8}$ & $7.2 \times 10^{8}$ & $5.6 \times 10^{8}$ & $5.7 \times 10^{5}$ & $6.6 \times 10^{5}$ \\
\hline Rod-shaped LAB & $2.9 \times 10^{6}$ & $2.4 \times 10^{6}$ & $5.8 \times 10^{7}$ & $1.2 \times 10^{7}$ & $1.2 \times 10^{8}$ & $1.0 \times 10^{8}$ & $8.2 \times 10^{7}$ & $9.1 \times 10^{7}$ & $4.8 \times 10^{7}$ & $1.2 \times 10^{8}$ & $6.2 \times 10^{7}$ & $1.6 \times 10^{7}$ \\
\hline $\begin{array}{l}\text { Heterofermentative } \\
\text { LAB }\end{array}$ & $1.0 \times 10^{7}$ & $0.0 \times 10^{0}$ & $5.7 \times 10^{7}$ & $2.3 \times 10^{7}$ & $5.5 \times 10^{6}$ & $5.5 \times 10^{6}$ & $5.2 \times 10^{6}$ & $1.1 \times 10^{8}$ & $8.3 \times 10^{7}$ & $1.3 \times 10^{8}$ & $5.5 \times 10^{6}$ & $6.4 \times 10^{6}$ \\
\hline Yeasts & $6.2 \times 10^{6}$ & $8.7 \times 10^{6}$ & $1.7 \times 10^{6}$ & $2.3 \times 10^{6}$ & $2.6 \times 10^{5}$ & $1.3 \times 10^{5}$ & $3.3 \times 10^{5}$ & $3.2 \times 10^{6}$ & $1.3 \times 10^{5}$ & $6.1 \times 10^{6}$ & $5.5 \times 10^{1}$ & $6.4 \times 10^{1}$ \\
\hline Moulds & $7.5 \times 10^{2}$ & $3.5 \times 10^{2}$ & $1.8 \times 10^{5}$ & $2.1 \times 10^{5}$ & $1.3 \times 10^{5}$ & $1.3 \times 10^{5}$ & $8.7 \times 10^{4}$ & $1.4 \times 10^{4}$ & $3.8 \times 10^{2}$ & $2.8 \times 10^{4}$ & $5.5 \times 10^{1}$ & $6.4 \times 10^{1}$ \\
\hline $\begin{array}{l}\text { Lactate-fermenting } \\
\text { clostridia spores }\end{array}$ & $3.0 \times 10^{0}$ & $0.0 \times 10^{0}$ & $3.3 \times 10^{1}$ & $1.4 \times 10^{1}$ & $4.2 \times 10^{1}$ & $2.3 \times 10^{1}$ & $4.4 \times 10^{1}$ & $1.5 \times 10^{2}$ & $7.6 \times 10^{1}$ & $2.2 \times 10^{2}$ & $5.6 \times 10^{2}$ & $7.7 \times 10^{2}$ \\
\hline $\begin{array}{l}\text { Propionic acid } \\
\text { bacteria }\end{array}$ & $8.3 \times 10^{3}$ & $1.0 \times 10^{4}$ & $1.4 \times 10^{4}$ & $6.0 \times 10^{3}$ & $9.5 \times 10^{4}$ & $7.9 \times 10^{4}$ & $8.7 \times 10^{4}$ & $1.7 \times 10^{6}$ & $1.6 \times 10^{4}$ & $2.9 \times 10^{6}$ & $1.3 \times 10^{3}$ & $1.1 \times 10^{3}$ \\
\hline
\end{tabular}

${ }^{*}$ Mean value is equivalent to median value.

${ }^{a} \mathrm{SD}$, standard deviation. 
Table VIII. Effect of lysozyme addition to milk on Pannerone cheese fermentations: content of organic acids $\left(\mathrm{g} \cdot \mathrm{kg}^{-1}\right)$ after 6 days of warm room at $30^{\circ} \mathrm{C}$. Trials were performed in duplicate.

\begin{tabular}{lccccc}
\hline & \multicolumn{2}{c}{ Control } & & \multicolumn{2}{c}{ Lysozyme $\left(50 \mathrm{mg} \cdot \mathrm{kg}^{-1}\right)$} \\
\cline { 2 - 3 } \cline { 5 - 6 } & Mean & $\mathrm{SD}^{*}$ & & Mean & 8.5 \\
\hline Total solids & 579.8 & 2.0 & 589.4 & 0.00 \\
Lactose & 0.00 & 0.00 & 0.00 & 0.00 \\
Galactose & 0.07 & 0.06 & 0.00 & 0.86 \\
Lactic acid & $3.09^{\mathrm{a}}$ & 1.84 & $14.99^{\mathrm{b}}$ & 0.20 \\
Acetic acid & $0.40^{\mathrm{a}}$ & 0.17 & & $1.64^{\mathrm{b}}$ & 0.00 \\
Citric acid & 0.00 & 0.00 & 0.00 & 0.00 \\
Propionic acid & $1.27^{\mathrm{a}}$ & 0.51 & $0.10^{\mathrm{b}}$ & 0.00 \\
Butyric acid & $6.29^{\mathrm{a}}$ & 1.21 & $0.49^{\mathrm{b}}$ & 0.08 \\
pH & $5.69^{\mathrm{a}}$ & 0.10 & $5.11^{\mathrm{b}}$ &
\end{tabular}

Different letters in the same row mean that the values are significantly different $(P<0.01)$.

* SD, standard deviation.

Rows without superscripts did not present significant differences.

to temperature. Butyric acid concentration was significantly the lowest at $4{ }^{\circ} \mathrm{C}$. To have amounts of butyric acid similar to those usually found in Pannerone cheese from retail, it is necessary to maintain the temperature of the warm room at about $30{ }^{\circ} \mathrm{C}$. The storage of Pannerone cheese at a temperature higher than $30{ }^{\circ} \mathrm{C}$ did not affect the lactate fermentations, but increased significantly the total solid contents of the cheese. In order to obtain a cheese with traditional characteristics, the holding of cheese to correct temperature for the time necessary to accomplish the specific fermentations is a critical point. The length of the holding time of Swiss cheese into the warm room at $25{ }^{\circ} \mathrm{C}$ was related to its propionic acid content [19]. The holding of the curd of Castelmagno for 3 days under whey at uncontrolled room temperature allowed for a sharp decrease of $\mathrm{pH}$ to 4.78 and a high formation of lactic acid. However, propionic and butyric acid contents were $<1.5$ and $0.2 \mathrm{~g} \cdot \mathrm{kg}^{-1}$, respectively, by the end of ripening [12].

The microbial counts confirmed that the microflora of raw milk was comparable in almost all the trials and the cocci-shaped $\mathrm{LAB}$ were the most numerous (data not shown). After the first day from cheesemaking (Tab. VII), cocci-shaped LAB, E. coli, other coliform bacteria and coagulase-positive staphylococci were the more represented bacteria, in the order mentioned. However, the results were characterized by a large expected variability among the replicated trials as shown by the differences between the mean value and the median value. On the contrary, after 6 days an important reduction of coagulase-positive staphylococci count was observed (Tab. VII). The higher the temperature of the warm room, the higher the reduction of viable cell number of staphylococci. Coliforms and E. coli counts were substantially stable, with the exception of the cheese at $38{ }^{\circ} \mathrm{C}$ where an important count reduction was measured. The highest counts of heterofermentative and rod-shaped LAB were observed at 30 and $25^{\circ} \mathrm{C}$, respectively, PAB counts were higher at cheese temperature between 25 and $30{ }^{\circ} \mathrm{C}$, according to what happens during the warm room period for the Emmental cheese [28]. The number of lactate-fermenting clostridia was generally low, according to the limit of the analytical method employed that counted only the spores. 


\subsection{Influence of butyric clostridia on Pannerone cheese quality}

Butyric acid can originate from animal, i.e. lamb paste rennet, or microbial lipase activity or from lactate fermentation. The absence of lipolytic bacteria and the numbers of moulds (Tabs. I and IV) minimized the role of microbial lipases. However, it is not possible to exclude the activity of the native milk lipoprotein lipase, because Pannerone is made using raw milk. To demonstrate the involvement of the lactatefermenting clostridia, in particular the vegetative cells, in the production of butyric acid during the warm room step, lysozyme was added to the raw milk used for Pannerone manufacture. Lysozyme is usually and successfully used in Grana Padano cheesemaking to prevent late blowing. While spores are resistant to lysozyme, lysozyme lyses the cell wall of the mature vegetative cells of $C$. tyrobutyricum and Clostridium butyricum or that of the new vegetative cell during the outgrowth from the spore [7, 22]. The amount of lysozyme used in Swiss-type cheese to prevent lactate fermentation by clostridia without blocking the propionic fermentation is usually lower than the $20 \mathrm{mg} \cdot \mathrm{L}^{-1}$ added to milk for Grana Padano [7]. Hence, considering the favourable conditions for clostridia in Pannerone cheese-making and the need to allow lactic acid fermentation, the lysozyme amount used was limited to $50 \mathrm{mg} \cdot \mathrm{L}^{-1}$. Lysozyme, in spite of the high amount used, did not inhibit lactic acid fermentation by the heterogeneous indigenous flora of raw milk, as shown by a lactic acid content of $15 \mathrm{~g} \cdot \mathrm{kg}^{-1}$ measured after 6 days at $30^{\circ} \mathrm{C}$, similar to that observed in control cheeses after 4 days in warm room (Tab. V), and by the concurrent depletion of lactose and galactose. The butyric and propionic acid contents $\left(0.5\right.$ and $0.1 \mathrm{~g} \cdot \mathrm{kg}^{-1}$, respectively) were significantly lower $(P<0.01)$ than those of the control cheese made without lysozyme (Tab. VIII). The $\mathrm{pH}$ of the curd during the warm room time decreased to about 4.9 , but this is not inhibitory for butyric clostridia [7]. Their growth and the consequent utilization of lactate contributed to raise the $\mathrm{pH}$ value of the cheese. The $\mathrm{pKa}$ value of butyric acid (4.86) is lower than that of lactic acid (3.86). The negative relation between lactate and butyrate content in lysozyme cheese demonstrated that inhibiting lactate-fermenting clostridia by the addition of high amount of lysozyme also inhibits butyric acid production.

Propionic acid content was also significantly lower (Tab. VIII) in cheeses made using lysozyme. This could be due to an inhibitory effect on PAB of the high dose of lysozyme used. Moreover, the inhibition of butyric clostridia growth and the lack of lactate fermentation maintained the curd at a low $\mathrm{pH}$ which is unfavourable for the growth of PAB.

The amount of acetic acid was higher in cheese made using lysozyme than that in the control. This result could be explained both by the low activity of lysozyme against gram-negative bacteria and by the lack of acetate utilization as a consequence of inhibition of germination of butyric clostridia spores [7].

\section{CONCLUSIONS}

Pannerone is a cheese obtained from raw milk, without starter addition and without salting, using a traditional technology unchanged over the years. This study demonstrated that the most important step to preserve the characteristics of Pannerone cheese is the period when the cheese is in the warm room at $30{ }^{\circ} \mathrm{C}$ up to 6 days. The presence and the role of coliform bacteria giving the typical characteristics of the cheese is confirmed, but it is shown for the first time that butyric clostridia and $\mathrm{PAB}$ are fundamental and their growth is favoured by the unique prolonged time of warm room. The presence of high amounts 
of butyric and propionic acids is important for the characteristics of the cheese. Fermentation of lactose to lactate firstly, and the following lactate conversion to butyric and propionic acids are responsible for the $\mathrm{pH}$ changes of the curd during the warm room time. Like all the raw milk cheeses with a short ripening time, Pannerone cheese may be considered as potentially hazardous. However, pathogenic bacteria always are absent in all the 26 samples analysed. It can be hypothesized that holding the curd at low $\mathrm{pH}$ value $(<5.0)$ during the first 4 days of warm room at a temperature of about $30{ }^{\circ} \mathrm{C}$, and the presence of a mixture of organic acids (lactic, butyric, propionic and acetic) could contribute to control the pathogenic bacteria. Lowering the temperature of the warm room at or below $25^{\circ} \mathrm{C}$, the fermentation profile of Pannerone cheeses deeply changes.

Acknowledgements: The authors thank Mr. A. Carena for giving access to his dairy and discussing the cheese-making technology, Dr. L. Bacchetta for his contribution during his graduate studies. This study was partially supported by the Agricultural Research Service of Regione Lombardia (Italy) through the research project FORTISI.

\section{REFERENCES}

[1] Addis M., Pirisi A., Di Salvo R., Podda F., Piredda G., The influence of the enzymatic composition of lamb rennet paste on some properties of experimentally produced PDO Fiore Sardo cheese, Int. Dairy J. 15 (2005) 1271-1278.

[2] Akalin A.S., Gonc S., Akbas Y., Variation in organic acid content during ripening of pickled white cheese, J. Dairy Sci. 85 (2002) 1670-1676.

[3] Bacci C., Paris A., Brindani F., Ruolo di Clostridium spp. in alterazioni del Parmigiano Reggiano riconducibili a gonfiore tardivo, Annali Facoltà Medicina Veterinaria Parma XXII (2002) 221-231.
[4] Baer A., Riba I., Interactions between propionic bacteria and thermophilic lactic acid bacteria, Lait 79 (1999) 79-92.

[5] Bodini T., Guicciardi A., Craveri R., Studio microbiologico e chimico di alcuni formaggi a pasta molle e riconoscimento della microflora eumicetica interessata, Latte 43 (1969) 711-719.

[6] Bouzas J., Kantt C.A., Bodyfelt F., Torres J.A., Simultaneous determination of sugars and organic acids in cheddar cheese by high performance liquid chromatography, J. Food Sci. 56 (1991) 276-278.

[7] Carini S., Mucchetti G., Neviani E., Lysozyme: activity against clostridia and use in cheese production - a review, Microbiologie Aliments Nutrition 3 (1985) 299-320.

[8] Cerf O., Bergere J.L., La numération des spores de Clostridium et son application au lait et aux produits laitiers. Numération des différents groupes de Clostridium, Le Lait 48 (1968) 501-519.

[9] Chavez-Lopez C., De Angelis M., Martuscelli M., Serio A., Paparella A., Suzzi G., Characterization of the Enterobacteriaceae isolated from an artisanal ewe's cheese (Pecorino Abruzzese), J. Appl. Microbiol. 101 (2006) 353-360.

[10] Collins F.Y., McSweeney P.L.H., Wilkinson M.G., Lipolysis and free fatty acid catabolism in cheese: a review of current knowledge, Int. Dairy J. 13 (2003) 841-866.

[11] Del Forno G., Il formaggio Pannerone, Mondo Latte 36 (1982) 431-433.

[12] Dolci P., Alessandria V., Rantsiou K., Rolle L., Zeppa G., Cocolin L., Microbial dynamics of Castelmagno PDO, a traditional Italian cheese, with a focus on lactic acid bacteria ecology, Int. J. Food Microbiol. 122 (2008) 302-311.

[13] Freitas C., Malcata X.F.M., Microbiology and biochemistry of cheeses with Appélation d'Origine Protegée and manufactured in the Iberian Peninsula from ovine and caprine milks, J. Dairy Sci. 83 (2000) 584-602.

[14] IDF, Determination of the Protein Content of Processed Cheese Products, IDF Standard 25, Int. Dairy Fed., Brussels, Belgium, 1964.

[15] IDF, Determination of the Ash Content of Processed Cheese Products, IDF Standard 27, Int. Dairy Fed., Brussels, Belgium, 1964. 
[16] IDF, Milk - Determination of Fat Content (Gerber Butyrometers), IDF Standard 105, Int. Dairy Fed., Brussels, Belgium, 1981.

[17] IDF, Cheese and Processed Cheese - Determination of the Total Solids Content (Reference Method), IDF Standard 4A, Int. Dairy Fed., Brussels, Belgium, 1982.

[18] Ingham S.C., Hassler J.R., Tsai Y.-W., Ingham B.H., Differentiation of lactate-fermenting gas-producing Clostridium spp. isolated from milk, Int. J. Food Microbiol. 43 (1998) 173-183.

[19] Ji T., Alvarez V.B., Harper W.J., Influence of starter culture ratios and warm room treatment on free fatty acid and amino acid in Swiss cheese, J. Dairy Sci. 87 (2004) 1986-1992.

[20] Le Bourhis A.G., Doré J., Carlier J.P., Chamba J.F., Popoff M.R., Tholozan J.L., Contribution of Clostridium beijerinckii and Clostridium sporogenes in association with Clostridium tyrobutyricum to the butyric fermentation in Emmental type cheese, Int. J. Food Microbiol. 113 (2007) 154-163.

[21] Macedo A.C., Malcata X.F., Changes in the major free fatty acids in Serra cheese through ripening, Int. Dairy J. 6 (1996) 1087-1097.

[22] Mucchetti G., Neviani E., Microbiologia e tecnologia lattiero casearia, Qualità e sicurezza, Tecniche Nuove, Milano, Italy, 2006.

[23] Ottogalli G., Galli A., Rondinini G., Volonterio G., La microbiologia del formaggio Pannerone, Industria Latte 11 (1975) 7-17.
[24] Pirisi A., Pinna G., Addis M., Piredda G., Mauriello R., De Pascale S., Caira S., Mamone G., Ferranti P., Addeo F., Chianese L., Relationship between the enzymatic composition of lamb rennet paste and proteolytic, lipolytic pattern and texture of PDO Fiore Sardo ovine cheese, Int. Dairy J. 17 (2007) 143-156.

[25] Prieto B., Franco I., Fresno J.H.M., Bernardo A., Carballo J., Picon BejesTresviso blue cheese: an overall biochemical survey throughout the ripening process, Int. Dairy J. 10 (2000) 159-167.

[26] Savini E., Il Pannerone, Bollettino Istituto Sperimentale di Caseificio n. 8, La Moderna, Lodi, Italy, 1950.

[27] Thierry A., Madec M.N., Enumeration of propionibacteria in raw milk using a new selective medium, Lait 75 (1995) 315-323.

[28] Thierry A., Salvat-Brunaud D., Madec M.N., Michel F., Maubois J.-L., Affinage de l'Emmental : dynamique des populations bactériennes et évolution de la composition de la phase aqueuse, Lait 78 (1998) 521-542.

[29] Tripi V., Indagine sulla composizione chimica del formaggio Pannerone, Mondo Latte 34 (1980) 244-246.

[30] Zago M., Bonvini B., Martin Platero A.M., Mucchetti G., Carminati D., Giraffa G., Characterisation of Escherichia coli isolated from raw milk cheeses, Ann. Microbiol. 57 (2007) 49-54. 